\title{
Investigation Into The Factors Influencing Tendering Duration Stipulations By Public Building Clients In Nigeria.
}

\author{
S.C Ugochukwu, and K.C Okolie \\ 1 Department of Quantity Surveying, Nnamdi Azikiwe University, Awka. \\ 2 Department of Building Nnamdi Azikiwe University, Awka
}

\begin{abstract}
The study intensively examines those critical factors that Public building clients in Nigeria often take into consideration before allotting time frame for contractors to submit their tenders. To achieve this, a number of factors were first obtained via oral interviews with public building clients-ministries, parastatals, agencies and their professional consultants, then formally presented to 45 respondents all involved in the Nigerian public tendering process to be ranked. As such, the rank order of importance and percentage rating were obtained for each factor. The study observed that seven factors, namely: delays in annual national budget approval, Bill of quantities structure, project complexity, foreign procurement, adequacy of tender documents, reduction in number of tenderers and additional revenue all influenced the decisions of public clients with respect to time granted for receipt of bids. The ranking exercise revealed that delays in the approval of federation budget came topmost with a rating of $84.9 \%$, while reduction in number of tenderers came least with a $46.7 \%$ rating. Consequently, the study was inclined to conclude that these vital areas call for close attention, if tendering duration is to be sufficiently managed in order to reduce the negative impact of such factors on the quality of tendering practice in the country and improve success and transparency of public building procurement. The study thus recommended that there must be a political will on the part of the presidency and legislature to secure timely budget approvals to reduce pressure on procuring entities to observe standard procurement benchmarks and for an attitudinal and professional change on the part of tendering professionals, to observe better pre-contract planning techniques to justify huge resources spent from Government coffers for building projects.
\end{abstract}

Key Words: - Clients, Factors, Investigation, Public Buildings, Tendering Duration, Nigeria

\section{INTRODUCTION}

According to Adetola (2000), tendering is an invaluable aspect of project procurement or delivery system all over the world. Rarely would there be a public project that has not gone through one form of tendering or the other. Lou and Alshawi (2009) further surmise that contracting is a risky business, with the tendering phase deemed to be the most critical and important.

Tendering is considered a common way of obtaining building and construction industry services. It has thus been defined as the list of processes to produce, display and manage tender documents by the client or consultant (Knowles, 1997), while Tendering for public construction focuses on the process of selecting a suitable contractor to execute a public project, by calling for tenders, often achieved by sending out tender drawings and a bill of quantities or a specification, to receive prices in the form of estimates. It however, also includes actions to perform bidding by interested contractors in order to win the contract by responding to tenders with their capabilities and skills formation.

Prior to the submission of completed tenders and subsequent selection of the most successful tender, a period of time is usually allowed for, or given to tenderers by the client or his consultants to prepare their estimates or proposals, and carry out all necessary activities that will enable them achieve it. Tamimi (2009) refers to this space of time as the tender period or duration and is defined to begin with the tender advertisement and to end with the closing or submission date for tenders.

Tender duration heavily depends on the type of tender (commercial, design and build or invited tender), size/scale, complexity and value of the project and the amount of information that needs to be disclosed by the tenderers (Bina, 2010). Unfortunately, in the Nigerian scenario, these determinants of a realistic tendering duration have consistently been overlooked.

The Public Procurement Act (2007), section 25(ii) stipulates:

"in the case of goods and works valued under national competitive bidding, the invitation for bids shall be advertised on the notice board of the procuring entity, any official websites of the procuring entity, at least two national newspapers, and in the procurement journal not less than six weeks before the dead line for submission of the bids for the goods and works" 
From the stipulations of the Act, and current tendering practice by public clients, two salient shortcomings have been observed, namely;

(a) The basis for the six weeks stipulated is unclear, which gives public clients or procuring entities the liberty of stipulating whatever periods they deem appropriate as long as it falls within the maximum stipulated time.

(b) In a number of cases, the six weeks stipulation is hardly adhered to by public sector clients due to a number of factors of their making or beyond their control which results in inadequate periods being stipulated for tenderers.

Neighbour (2006) asserts that to prepare a realistic tender during the tendering period, the anticipated activities that tenderers will typically need to carry out are to measure the scope of the services being sought, obtain prices from their own suppliers and sub-contractors, visit the site, assess the tender and contract conditions, assess their capacity to undertake the work, clarify any inconsistencies or other queries with the purchaser, document the tender bid. The Contract documents need to be thoroughly examined to ensure that all conditions that are likely to affect the duration and cost of the project are not overlooked. These actions on the part of the contractor require considerable time to accomplish.

The tender process carries with it substantial dangers (Nosworthy, 2001), while the adequacy of time allowed for it is considered a typical risk in a building project (Neighbour, 2006). It should be remembered that the lowest tenderer is often the one that has made the biggest mistake and during project commencement may likely result in large and frivolous claims, and/or project abandonment, as the contractor may discover that the unrealistically low rates he submitted may not be sufficient to carry the building project to completion. Pressurizing tenderers into premature responses can therefore exacerbate the potential for errors.

Binnington (2004) is strongly of the opinion that one of the reasons why construction projects go wrong is insufficient time for tendering. The "lemming like rush" syndrome is reflected in the time periods granted to contractors to tender for work. Frequently employers and their professional teams or consultants, having spent months conceptualizing, designing and documenting a project, expect tenderers to respond in a hopelessly inadequate time period.

It is therefore important to ensure that sufficient time and pre-contract planning is provided for it, to enable contractors properly formulate their offers/submissions (Anonymous, n.d) and prepare accurate and competitive tenders. If the period is too short, it may result in either overpriced tenders to cover unforeseen risks or underpriced tenders completed without due care (Knowles, 1997).

\section{AIM/OBJECTIVES OF THE STUDY}

The aim of this study is to examine the critical factors that influence the decisions of public building clients before allotting time-frame for contractors to submit tenders in Nigeria. In this regard, the specific objectives of the research include:

- To identify the factors that influence public clients' decisions for time allocation;

- To critically examine the deadlines stipulated for tender submissions; and

- To rank the factors obtained in order of importance or necessity.

\subsection{OVERVIEW OF THE TENDERING CONCEPT}

\section{REVIEW}

The Aqua group (2006) defined tendering as: "A procedure to select a suitable contractor, at a time appropriate to the circumstances, and to obtain from him at the proper time an acceptable offer upon which a contract can be let" The tendering process in building projects begin with the analysis to ensure tender specification meets with end users need, followed by contractor selection, tender invitation and ending with contract awarding and contract monitoring (Mohemad, Hamdan, Othman and Noor, 2010). Figure 1 summarises the processes involved in the tendering phase of building procurement.

Table 1 The Tender process.

\begin{tabular}{|c|c|c|c|}
\hline \multicolumn{4}{|c|}{ PROCESS } \\
\hline Step1:Qualification & $\begin{array}{l}\text { Step 2: Tender invitation } \\
\text { and submission }\end{array}$ & $\begin{array}{l}\text { Step 3:Tender } \\
\text { Assessment }\end{array}$ & $\begin{array}{l}\text { Step 4: Tender } \\
\text { Acceptance }\end{array}$ \\
\hline $\begin{array}{l}\text { Firms attempt to gain } \\
\text { opportunity to be } \\
\text { considered for tender } \\
\text { by client }\end{array}$ & $\begin{array}{l}\text { Client invited firms to } \\
\text { complete and return } \\
\text { tender documents }\end{array}$ & $\begin{array}{l}\text { Client } \\
\text { completed } \\
\text { tenders to find suitable } \\
\text { contractors }\end{array}$ & $\begin{array}{l}\text { Client accepts most } \\
\text { suitable tender }\end{array}$ \\
\hline
\end{tabular}

Source: O'Connell (2010) 


\subsection{RELEVANCE AND CLIENTS OBJECTIVES OF TENDERING}

Seeley (1997) describes the tendering process as an attempt to clarify the factors which determine the most suitable tendering method to be adopted and the circumstances under which the clients interest are best served.

According to Knowles (1997).The tendering process enables clients to provide information to potential contractors in a fair and equitable way, give all suitably qualified potential tenders an opportunity to submit tenders to the client, enable the client to receive tenders from contractors in a confidential way, enable clients to evaluate the tenders and select the best value for money option. Tendering can thus provide advantages for clients and tenderers alike, including providing best value through competition, fair distribution of work opportunities, support of ethical standards, achievement of innovative results and creative solutions to client's needs.

Selecting a contractual relationship is very important as it establishes a good working relationship between contracting parties, which leads ultimately to a successful contract (Anonymous, 2001). Thus, the efficiency and effectiveness of the contract tendering process is crucial to the achievement of the desired goals and objectives of the construction project. Given the crucial role of tendering in the procurement process, it is expected that adequate attention be given to the process and the evolution of an effective framework for its use to ensure the realization of set national goals.

Similarly, Mohamed, Hamdan, Othman and Noor (2010) assert that the successful execution of a construction project is heavily impacted by making the right decision during tendering processes. Figure 1 shows a number of clients' objectives in the tendering process.

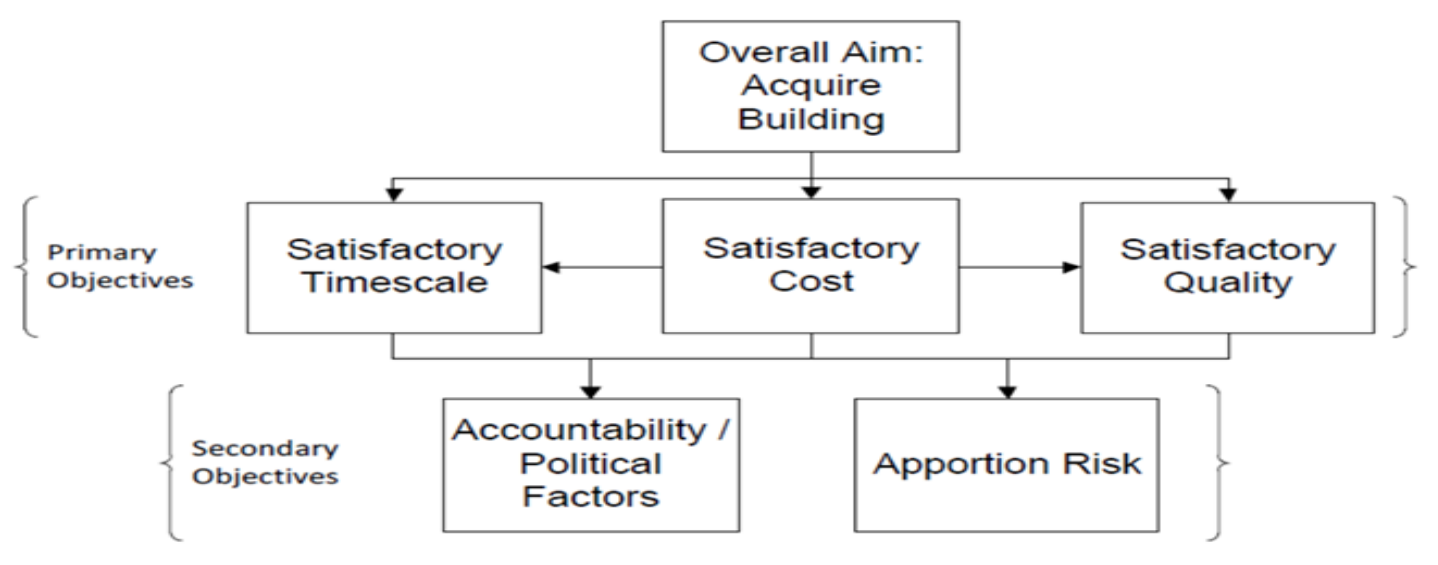

Figure1 Client's Objectives in Tendering. (O'Connell, 2010)

\subsection{Scope of the Nigerian Construction Industry and its Public Tendering system}

According to Olaloku (1987) the Nigerian construction industry includes all establishments involved with the erection of residential and non-residential buildings as well as civil engineering works. The industry has recorded some major achievements among which are the construction of housing estates, public buildings, industrial complexes and institutional buildings (Jambol and Yusufu, 2004). The building industry in Nigeria is dominated by the public sector to the extent that over $55 \%$ of building projects are sponsored by Federal, State and Local governments (Izam, 2008). The level of its activities dictates the state of the economy and it serves as an essential contributor to the process of development. Izam and Katun (2009) further assert that the pace of economic growth of any nation can be measured by the development of its infrastructure such as buildings

Tenders for public building projects in Nigeria are usually invited on a competitive basis, with the invitations to tender placed in the mass media such as the Federal tenders journal or the national papers. This is meant to encourage competitive tender costs. The present Government thus favours a contract tendering process that is open, competitive, fair and equitable to all bidders and which seeks to strategically focus on minimizing waste and reduce incidence of failure of public sector projects (Ayeni,1990).

The competitive tendering process is widely adopted at all levels of government in Nigeria, since it is believed that it gives best value for money and is an antidote to corruption through transparency and openness (Oladapo, 1999 ;Offong, 1999).

\section{METHODOLOGY}

The research focused on ascertaining the factors that influence clients' duration stipulations. These factors were first gathered and compiled based on interviews and discussions with various construction professionals: Quantity surveyors, Architects, Builders and Engineers all involved in public tendering for the Federal Government. 
The research went further to conduct using a questionnaire survey based on the complied list of factors and distributed to Forty five respondents, comprising 20 professional staff of the federal ministry of housing, 15 staff from the procurement unit of the Federal capital development authority (FCDA) and 10 principal partners of Quantity Surveying firms. Responses were received from all of them. They were asked to rank the factors in order of importance. The scale and weight given to each factor are as shown in Table 2. The questionnaires were also validated for reliability through a pilot study.

\section{DATA ANALYSIS}

\subsection{Ranking or factors in order of importance}

Data obtained from completed questionnaires was analyzed using the Ranking method to rank the most significant factors that influence tendering duration stipulations. The ranking method is a simple and most useful form of statistical scale where subjects are ranked according to some specific criteria or operationally defined characteristics or property. The point of the method is the power of visual presentation in identifying idiosyncrasies in relationships. The method proved useful, since basic data is not available in the form of numerical magnitudes. Weight or scores are assigned to a given number of factors. It overcomes the limitation and distorting effects of individual response or of group variation and presents the effects of each individual response. In ranking method of analysis, weights or scores of $1-\mathrm{n}$ are assigned to the factors to be measured. The rank sum is obtained using the formula:

$\mathrm{S}=\sum \mathrm{nw}$

Where $\mathrm{S}=$ rank sum

$\mathrm{n}=$ number of respondents

$\mathrm{w}=$ corresponding weight (score) of rank category.

In the ranking analysis procedure, relative indices (RI) were also attached to each ranked factors to be measured. These relative indices are a ranking index that reduces score attracted to the severity of items in an opinion survey to a common base. The index (RI) ranges from $0-1$. The item with the lowest relative index (RI) is first considered in the rank order.

$\mathrm{RI}=\mathrm{S} / \mathrm{x}(\mathrm{n})$

Where $\mathrm{x}=$ weight score or number of ranks and $\mathrm{n}=$ number of samples.

Percentage Ranking = RI x 100

\section{RESEARCH FINDINGS}

\subsection{Factors Influencing tendering Duration Stipulations}

Seven critical factors were identified from oral interviews and discussions with public tendering professionals. The authors further summarized them into three major categories or points of origin, namely:

- The client related factors

- The consultant related factors

- The external factors

Figure 2 depicts these categories and the sub factors for each in a pictorial form. It will also be observed that some sub-factors are common to all categories which can be explained by the fact that such subfactors can be caused by either the government client, their consultants or from external factors beyond the control of either of them.

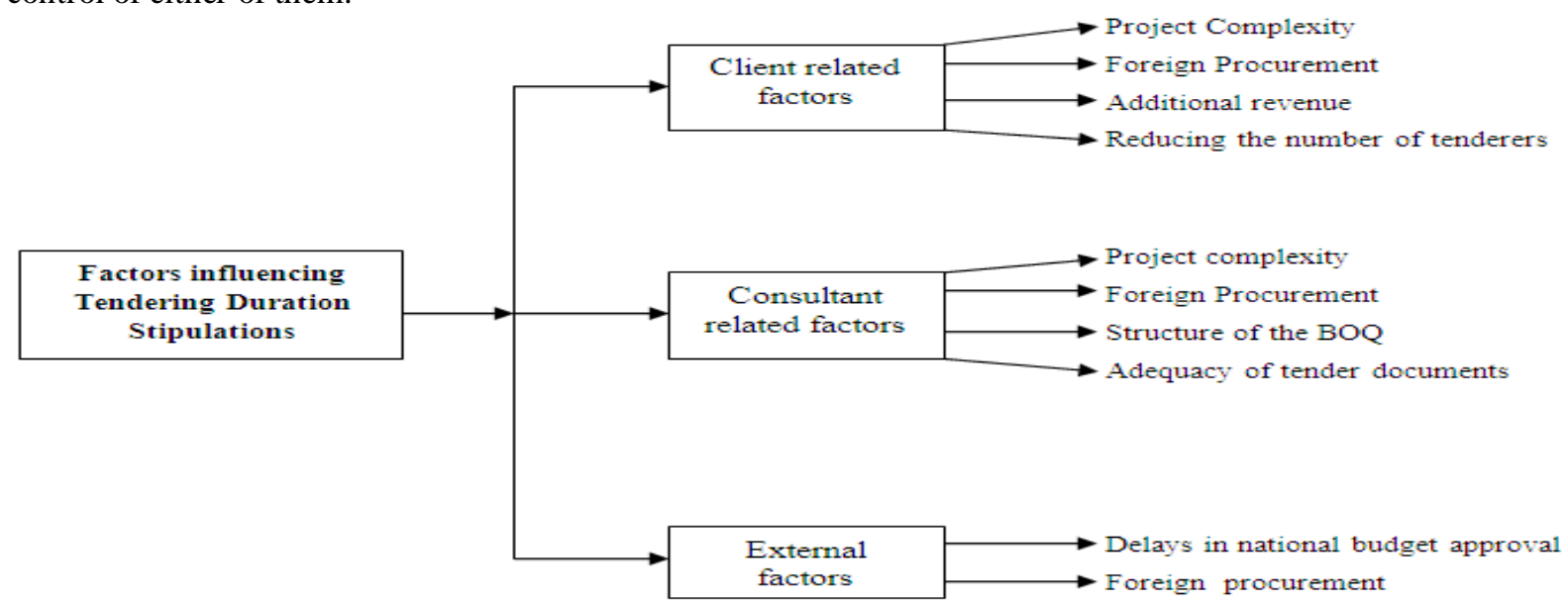

Figure 2 Factors influencing clients' tendering duration stipulations for public building projects (Authors' field study, 2013). 


\section{a) Project Complexity}

Public clients and their consultants sometimes desire complex projects to meet global standards. Project complexity is dependent on the extent and nature of specialist and main contractor's works involved. More time tends to be allotted for more complex projects since it is obvious that more enquiries will have to be made by the contractors from sub-contractors and suppliers. Also, the contractor will also need to seek further clarifications from the consultants, assess site conditions more thoroughly and prepare an acceptable method statement.

\section{b) Structure of the Bill of Quantities}

In certain cases of tendering, Bills of Quantities prepared by the Quantity Surveyor contains excessive provisional sums and as such tenderers for these projects are given less than sufficient time to submit their bids. This is because these consultants assume that such tenders are easier to price than those with completely quantified or measured work items.

\section{c) Foreign Procurement}

Public clients, consultants and certain top government functionaries, senators, prominent politicians (who may have vested interest in the proposed works, but not directly involved in the works) can have considerable influence on the nature or specifications for the materials to be used for the works. In this case, where materials specified are to be obtained from manufacturers or suppliers abroad (who may previously be known to these parties) considerable time is allotted for tenderers in view of the fact that extensive enquiries will have to be made concerning their purchase, transportation (shipping or freight) and installation/fixing costs.

\section{d) Approval of National Budget}

Insufficient time is sometimes given to contractors when there is delayed or late approval of the nation's annual budget by the president and legislature. Clients hasten bid submissions to let out works to contractors for works to begin quickly on sit before the fiscal year runs out. This is in a bid to avoid returning the monies budgeted for such works to the Government coffers or federation account.

\section{e) Additional Revenue}

Public sector clients sometimes, extend deadline for submission of tenders, not because of discrepancies found, but to make additional revenue, especially when costs of production of tenders have not been covered. In other words, the tendering duration can be extended when the client discovers that the monies realized from the sale of the tender documents has not equaled or surpassed the costs incurred in preparing the documents. He therefore deems it worthwhile to grant more time not necessarily for the purpose of given more tenderers opportunities to be selected but simply to make more revenue from sale of tenders.

\section{f) Reducing the number of Tenderers}

Insufficient time is sometimes deliberately stipulated by clients, to reduce the number of tenders. This is because they are of the view that a longer tendering duration tends to attract more tenders and makes examination and analysis more cumbersome. When the client envisages from past experience with the nature of the proposed works, he may decide to cut down on the time frame sensing that the more time given, the more new contractors may come into the picture and make tenders assessment even more tedious.

\section{g) Adequacy of Tender Documents}

Adequacy of tender documents supplied by the design and estimating team affects the duration of tendering stipulated and also on the time utilized on the part of contractors especially when drawings, specifications, bills of quantities, are not adequately prepared or certain vital information is missing which is essential to the tender cost, or there is no parity in the documents issued and as result, the process is ambiguous or does not reflect adequately the client's intentions of project requirements. This also creates difficulties for the tenderer who may either prepare a shoddy bid and spend less time in the entire process or take his time to make further enquiries to clarify inconsistencies, research more, thereby spending more than or less than the required time in the preparation. Additional time may have to be provided when such situations arise. 
VII. RESULTS AND DISCUSSIONS

Table 2: Ranking of factors that determine tendering duration stipulations in order of importance.

\begin{tabular}{|c|c|c|c|c|c|c|c|c|c|}
\hline \multirow[t]{2}{*}{ Identified Factors } & \multicolumn{5}{|c|}{ Respondents } & \multirow[t]{2}{*}{$\begin{array}{c}\text { Rank } \\
\text { Sum }\end{array}$} & \multirow[t]{2}{*}{$\begin{array}{l}\text { Relative } \\
\text { Index }\end{array}$} & \multirow[t]{2}{*}{$\begin{array}{c}\text { Rank } \\
\text { Order }\end{array}$} & \multirow[t]{2}{*}{ \% Rating } \\
\hline & 1 & 2 & 3 & 4 & 5 & & & & \\
\hline Project complexity & 0 & 4 & 8 & 17 & 16 & 180 & 0.800 & $3 \mathrm{rd}$ & 80.0 \\
\hline B.O.Q structure & 2 & 1 & 9 & 12 & 21 & 184 & 0.818 & 2nd & 81.7 \\
\hline Foreign procurement & 4 & 3 & 7 & 18 & 13 & 168 & 0.747 & 4 th & 74.7 \\
\hline $\begin{array}{l}\text { Delays in approval of } \\
\text { national budget }\end{array}$ & 1 & 3 & 3 & 15 & 23 & 191 & 0.849 & $1 \mathrm{st}$ & 84.9 \\
\hline $\begin{array}{l}\text { Adequacy of tender } \\
\text { documents }\end{array}$ & 0 & 6 & 12 & 16 & 11 & 167 & 0.742 & 5 th & 74.2 \\
\hline $\begin{array}{l}\text { Reduction in number of } \\
\text { tenderers. }\end{array}$ & 9 & 17 & 11 & 3 & 5 & 113 & 0.502 & 6th & 50.2 \\
\hline Additional revenue & 21 & 9 & 3 & 3 & 9 & 105 & 0.467 & 7 th & 46.7 \\
\hline
\end{tabular}

A careful examination of the Table 2 shows that there are seven factors that influence the tendering duration stipulated by clients. The results of the ranking exercise are also shown as obtained from the responses of clients/consultants on a 5 point scale in the following manner: Strongly agreed $=5$ points, agreed $=4$ points, strongly disagreed $=3$ points, disagreed $=2$ points, undecided $=1$ point. A simple arithmetic was assigned to convert the weightings into ranks. Hence the table was constructed, calculating the rank sum, relative index, rank order and percentage scores. The procedure for the ranking is as shown below. For example, delays in approval of national budget:

Ranking sum $(\mathrm{S})=\sum \mathrm{nw}$,

Where $\mathbf{n}$ is no of respondents and $\mathbf{w}$, the corresponding weight (score).

Therefore $S=(1 \times 1)+(3 \times 2)+(3 \times 3)+(15 \times 4)+(23 \times 5)=191$

Relative index $=\mathrm{S} / \mathrm{max}$ possible score $=191 /(5 \times 45)=191 / 225=0.849$

Percentage score $=0.849 \times 100=84.9 \%$

Hence, the rank order for factors as shown which depicts a close tie amongst factors 1 to 5 .

At a glance, it can also be clearly seen that delays in approval of the annual national budget is the most important factor that clients put into consideration before stipulating tendering duration for contractors, while making of additional revenue is the least which was also found to be subjective, depending on the preference of members of the tenders board and procurement unit of the relevant ministry or parastatals. From the course of interviews, the researcher also gathered, that this particular factor is quite sensitive, as some staff do not want to be associated with the issue, which in their view amounts to an unethical practice.

\section{SUMMARY, CONCLUSIONS AND RECOMMENDATIONS}

The study was primarily undertaken to identify, study and evaluate the scope of factors influencing stipulations of tendering durations by the Federal Government and as such, brought to limelight these factors so that fairness and transparency can be promoted in the public tendering system. The study was inclined to conclude that these factors affect the overall quality of the Nigerian tendering process.

From the foregoing findings obtained, the study hereby proffers as recommendations for implementation that firstly, great efforts should be made by the presidency and legislature towards securing timely approval of national budget so as to reduce pressure on procuring entities to observe procurement benchmarks. And secondly, for a general attitudinal and professional change on the part of public employees especially the tendering professionals, towards better precontract planning: that despite the fact that building projects are beneficial to the citizenry and the economy at large, rushing tender submissions may not be the best solution after all, as the probable later consequences of financial loss or project abandonment may far outweigh all monies, efforts and time spent on the entire tender process.

\section{REFERENCES}

[1] Adetola, F.O. (2000).How Efficient is the Open and Competitive Tendering System? In N.I.Q.S (Eds), Open and competitive tendering in the procurement of public and private sector projects(pp 59 - 72), Lagos: Nigerian institute of Quantity Surveyors.

[2] Anonymous, (n.d). Tendering in construction: An introduction. Retrieved from http://www.slideshare.net 
[3] Anonymous. (2011, March 3).Functions and Powers of the Bureau of Public Procurement. Businessday.Retrieve from http://www.businessdayonline.com/NG/index.php/law/the- specialists/1864/

[4] Aqua group. (2006). Pre-contract practice for Architects and Quantity surveyors. Hert: Granada publishing limited.

[5] Ayeni, O.J. (1990).Principles of tendering and estimating (2nd ed.).Lagos: Builders magazine limited.

[6] Bina, A. (2010).Pre-bidding planning: The construction manager. Retrieved from http://www.construction2u.blogspot.com

[7] Binnington, C.(2004).Why do construction projects go wrong? The civil engineering contractor. Retrieved from http://www.bca.co.za

[8] Izam, Y.D. (2008).Duration estimation accuracy among construction firms in Nigeria: A comparative study of foreign and local firms. Journal of environmental sciences, 1(2): $49-50$.

[9] Izam, Y. D. \& Katun, I. (2009).An appraisal of project needs of public building clients in Nigeria. Nigerian Journal of Construction Technology and Management.10(1\&2): 107- 111

[10] Jambol, D.D. \& Yusufu, M. I. (2004). An appraisal of the National construction policy goals on major stakeholders in the construction industry. Nigerian Journal of Construction Technology and Management 5(1): 63-75.

[11] Knowles, R.I. (1997).Tendering for public construction and related consultancy services. Victoria: Office of building and infrastructure development. Retrieved from http://www.building commission.com.au

[12] Lou, C. E. and Alshawi, M.(2009). Critical success factors for E-tendering Implementation in construction collaborative environments: People and process rules. Retrieved from http://www.itcon.org

[13] Mohemad, R.; Hamdan, A.; Othman, Z.A. and Noor, M.M. (2010). Decision support systems in construction tendering. International journal of computer science issues (IJCSI), 7(2): $\quad 35 \quad-45$. Retrieved from http://www.ijcsi.org/papers

[14] Neighbour, K. (2006). A guide to construction projects: Best practices for the procurement and delivery of projects (2nd ed.). Retrieved from http://aca.org.au

[15] Norsworthy, I. (2001).A practical guide to effective contract management: Pre-contractual negotiations and new concepts in contracting. Paper presented at the I.E.S conference, Stamford. Retrieved from http://www.hospart.com.au

[16] O'Connell, L (2010). Electronic Tendering: Recognizing a More Effective Use of Information Communications Technology in the Irish Construction Industry. M. Phil thesis. Dublin Institute of Technology.

[17] Offong, C.O. (1999).Open and competitive tendering: A panacea for corruption in project procurement. In N.I.Q.S (Eds.), Open and competitive tendering in the procurement of public and private sector projects(pp 37 -58),Lagos: Nigerian Institute of Quantity surveyors.

[18] Oladapo, A.M. (1999). Open and competitive tendering: A vehicle for transparency and accountability in Governance. In N.I.Q.S (Eds.), Open and competitive tendering in the procurement of public and private sector projects(pp 1-12), Lagos: Nigerian Institute of Quantity surveyors.

[19] Olaloku, F.A. (1987). The second tier foreign exchange market and the construction industry in Nigeria: Options and challenges. The quantity surveyor, 4(1): $4-8$.

[20] Seeley, I.H. (1997).Quantity surveying practice (2nd ed.).London: Macmillan press limited.

[21] Tamimi, A. (2009). Tendering tips and traps. Retrieved from http://www.newsweavwe.ie/altamimi/e 